\title{
Investment Management in Early-Stage Entrepreneurship in Modern National Economies
}

\author{
Iuliia Pinkovetskaia ${ }^{1, *}$, Irina Gruznova ${ }^{2}$, Anton Lebedev $^{2}$, Larisa Tsybina $^{2}$ \\ ${ }^{1}$ Department of the Economic Analysis and State Management, Institute of Economics and Business, Ulyanovsk State University, \\ Ulyanovsk, 432000, Russia \\ ${ }^{2}$ Department of the English Language for Professional Communication, Foreign Languages Faculty, N. P. Ogarev's Mordovia State \\ University, Saransk, 430005, Russia
}

Received February 19, 2021; Revised March 12, 2021; Accepted April 22, 2021

\section{Cite This Paper in the following Citation Styles}

(a): [1] Iuliia Pinkovetskaia, Irina Gruznova, Anton Lebedev, Larisa Tsybina , "Investment Management in Early-Stage Entrepreneurship in Modern National Economies," Universal Journal of Accounting and Finance Vol. 9, No. 2, pp. 245 251, 2021. DOI: 10.13189/ujaf.2021.090214.

(b): Iuliia Pinkovetskaia, Irina Gruznova, Anton Lebedev, Larisa Tsybina (2021). Investment Management in Early-Stage Entrepreneurship in Modern National Economies. Universal Journal of Accounting and Finance, 9(2), 245 251. DOI: 10.13189/ujaf.2021.090214.

Copyright $\bigcirc 2021$ by authors, all rights reserved. Authors agree that this article remains permanently open access under the terms of the Creative Commons Attribution License 4.0 International License

\begin{abstract}
The purpose of the paper is to evaluate indicators describing the participation of men and women in external financing of new small and medium businesses in different countries. As the initial information in our study, we used the data obtained from the implementation of the Global Entrepreneurship Monitoring Project. The study evaluated the indicators that characterize the participation of men and women in investments in emerging businesses, and the average values of the corresponding contributions. The scientific novelty and originality of our study are as follows: indicators on external investment in SMEs by men and women in different countries have been assessed; six indicators describing external investments for start-up entrepreneurs were modelled; males' participation in external financing of SMEs has shown to be higher in most countries than in women, and there is a gender gap in external funding; average values of deposits in investments for start-up entrepreneurs have been established; significant differences in the values of the six indicators under consideration by country are shown; countries with high and low values of each of the six indicators are represented. The results are of theoretical and practical importance for government bodies and entrepreneurs. The methodological approach to assessing external financing of new SMEs proposed in the article can be applied in further studies. The new knowledge gained is of interest and can be used in the educational process in universities. Further research
\end{abstract}

may aim at detailing the structure of external financing recipients among entrepreneurs.

Keywords New Entrepreneurship, Investment in Entrepreneurship, External Financing, Gender Gap, Participation of Women and Men in Financing

\section{Introduction}

In recent years, the national economies have significantly grown in terms of their business sector. The entrepreneurship development copes with the issue of raising the production efficiency in goods and services, creating new jobs, increasing competition in the existing markets, and also solving a wide range of social problems $[1,2]$. Entrepreneurial initiatives are a key element in determining the competitiveness of an economy. Modern countries are conditioned by the entrepreneurs playing an essential role in advancing technological progress and innovation. The significance of entrepreneurs specifically increases over the periods of economic crises, since small and medium-sized businesses are more adaptable to the alterations and fluctuations in market conditions. Therefore, the relevant issue for most countries is the establishing of the valid amount of new small and medium enterprises (SMEs). According to the research results, findings and 
conclusions, creating an SME demands the availability of financial resources. At the same time, it is challenging to apply both traditional (bank loans) and alternative (asset-based lending, factoring, purchase order finance, warehouse receipts, leasing) financing tools [3, 4]. Consequently, in recent years multiple countries have paid significant attention to attracting funds from individuals to finance the emerging SMEs $[5,6]$. This phenomenon is called external financing of entrepreneurs. Our paper addresses the current issue of assessing the current levels of external financing for the business sector in different countries. This should improve understanding of the full range of financial instruments and new approaches to SME investment alternative to traditional bank lending.

An analysis of the gender dimensions of such funding seems relevant. That is, a study of the characteristics of external financing of new SMEs by women and men. In addition, it is logical, in our opinion, to determine whether there is a gender gap in the behavior of women and men involved in the investment of entrepreneurial activities. It should be noted that the gender profile of external financing of SMEs has not been sufficiently addressed in publications to date.

In our study, we answer the following questions:

1. What is the proportion of women living in different countries who participate in external financing of new SMEs?

2. What is the proportion of men living in different countries who participate in external financing of new SMEs?

3. Is there a gender gap in the participation of women and men in informal financing of start-up entrepreneurs by country?

4. What is the amount of the external funding for new SMEs provided by women?

5. What is the amount of the external funding for new SMEs provided by men?

6. Is there a gender gap in external financing of new SMEs between women and men?

7. Are there significant differences in funding for new SMEs across countries?

The purpose of the article is to assess indicators describing the external financing of new SMEs by men and women. At the same time, we solved the following problems. In the first phase, empirical data were generated describing the participation of women and men in different countries in the investment processes of entrepreneurs starting their own businesses. The second phase determined the proportion of men and women who participated in external financing of new entrepreneurs in the total number of these gender groups by country. In the third phase, the average contribution of men and women to SME investment was determined. Countries with high and low levels of external financing for SMEs were also identified. For these countries, both location and average incomes of the population were analyzed.

\section{Review of Literature}

The relevance of the study of investment in the emerging small and medium enterprises (SMEs) has been highlighted in many scientific studies carried out in recent years. At the same time, one of the main difficulties hindering the creation of such enterprises is the lack of sufficient financial resources for start-up entrepreneurs creating these enterprises [3, 7]. The problem is complicated by the fact that start-up entrepreneurs find it difficult to acquire credit funds. This is indicated by many authors $[8,9]$. They draw attention to the lack of real estate and other assets necessary for bank lending for such entrepreneurs. Financial constraints can be particularly severe in the case of the use of intangible assets, as they are difficult to use as collateral in traditional debt relations [10]. In addition, the recent crises increase the requirements of banks when issuing loans. Therefore, in the context of crises, the banking credit constraints experienced by SMEs in most countries are increasing [11].

It should be noted that recent scientific publications have focused on the call for more systematic consideration of external financing of start-up entrepreneurs through informal investment. Of greatest interest are works published in recent years that consider the theoretical and practical aspects of improving the efficiency of informal investments in small and medium-sized enterprises $[12,13$, $14,15]$. While implementing external financing, investors require maximum information transparency from the enterprises they intend to invest their funds [16]. Thus, the complete data is capable of facilitating the stable interaction among entrepreneurs and investors [17].

\section{Materials and Methods}

The external investment of SMEs is carried out by citizens of various countries for the trusted entrepreneurs who own these businesses. At the same time, as indicated in a number of studies $[18,19]$ the major investors are family members, friends, and acquaintances. In addition, these may be other people interested in creating and developing a specific new business. Crowdfunding method is frequently used [13, 20, 21]. In the case of crowdfunding, external investors focus on the personality of the entrepreneur, their knowledge and competence.

Our study examined the evaluation of six indicators characterizing the gender dimensions of external investment in SMEs across 59 countries in 2018-2019:

- The proportion of women participating in external financing of new SMEs in the total adult female population of the country;

- The proportion of men participating in external financing of new SMEs in the total adult male population of the country;

- The ratio of participation rates in external financing of new SMEs for women and men; 
- The average financial contributions to new SMEs by women living in different countries;

- The average financial contributions to new SMEs by men living in different countries;

- Ratio of average contributions of women and men to new SMEs.

As initial information, our study used the data obtained from the implementation of the Global Enterprise Monitoring project for 2018-2019 [22].

Our study involved testing three of the following hypotheses:

- hypothesis 1 - the values of the six indicators under consideration have a significant differentiation between different countries;

- hypothesis 2 - the territorial location of countries does not significantly affect the values of each of the six indicators;

- hypothesis 3 - the level of income of the population in the countries under consideration does not significantly affect the values of each of the six indicators.

The evaluation of the values of the six indicators under consideration was based on economic and mathematical modeling of initial empirical data. Normal distribution density functions were used as models, the method of development of which is given in the article [23]. The functions obtained allow to determine the average values of each of the six indicators for the countries under consideration, as well as the ranges of their variations typical for most countries. In addition, the study identified countries in which the values are higher than the upper and smaller than the lower limits of the ranges. The range limits for $68 \%$ of countries were determined on the basis of average values and corresponding standard deviations. The lower limit of the interval is equal to the difference between the average value and the standard deviation, and the upper limit is their sum.

\section{Results of the Computational Experiment}

During the computational experiment, economic and mathematical modeling was carried out on the basis of empirical data. The models are functions of the normal distribution density. The functions (y) that describe the distribution of the six indicators (x) across all 57 countries are shown below:

- the proportion of women participating in the financing of new SMEs in the total adult female population, $\%$

$$
y_{1}\left(x_{1}\right)=\frac{77.33}{1.97 \times \sqrt{2 \pi}} \cdot e^{\frac{-\left(x_{1}-3.23\right)^{2}}{2 \times 1.97 \times 1.97}} ;
$$

the proportion of men participating in the financing of new SMEs in the total male adult population, $\%$

$$
y_{2}\left(x_{2}\right)=\frac{94.25}{2.55 \times \sqrt{2 \pi}} \cdot e^{\frac{-\left(x_{2}-4.86\right)^{2}}{2 \times 2.55 \times 2.55}}
$$

- the ratio of SMEs women and men funding participation rates

$$
y_{3}\left(x_{3}\right)=\frac{6.44}{0.20 \times \sqrt{2 \pi}} \cdot e^{\frac{-\left(x_{3}-0.63\right)^{2}}{2 \times 0.20 \times 0.20}} ;
$$

the average financial contribution to SMEs for women, thousand dollars

$$
y_{4}\left(x_{4}\right)=\frac{281.71}{3.14 \times \sqrt{2 \pi}} \cdot e^{\frac{-\left(x_{4}-4.46\right)^{2}}{2 \times 3.14 \times 3.14}}
$$

- the average value of financial contribution to SMEs for men, thousand dollars

$$
y_{55}\left(x_{4}\right)=\frac{215.43}{5.28 \times \sqrt{2 \pi}} \cdot e^{\frac{-\left(x_{5}-5.90\right)^{2}}{2 \times 5.28 \times 5.28}}
$$

- the value of average deposits for women and men

$$
y_{6}\left(x_{6}\right)=\frac{14.91}{4.10 \times \sqrt{2 \pi}} \cdot e^{-\frac{\left(x_{6}-0.72\right)^{2}}{2 \times 0.28 \times 0.28}} \text {. }
$$

The quality of the developed models was evaluated using three criteria: by the Kolmogorov-Smirnov, the Pearson and the Shapiro-Wilk tests. Calculated values of criteria are given in Table 1.

Table 1. Calculated values of criteria

\begin{tabular}{|l|c|c|c|}
\hline \multirow{2}{*}{ Indicators } & \multicolumn{2}{|c|}{ Criteria } \\
\cline { 2 - 4 } & $\begin{array}{c}\text { The } \\
\text { Kolmogorov-Smirnov test }\end{array}$ & $\begin{array}{c}\text { The Pearson } \\
\text { test }\end{array}$ & $\begin{array}{c}\text { The Shapiro-Wilk } \\
\text { test }\end{array}$ \\
\hline $\begin{array}{l}\text { Proportion of women participating in the financing of new SMEs in the } \\
\text { total adult female population }\end{array}$ & 0.07 & 1.56 & 0.96 \\
\hline $\begin{array}{l}\text { Proportion of men participating in the financing of new SMEs in the } \\
\text { total male adult population }\end{array}$ & 0.06 & 2.06 & 0.96 \\
\hline Ratio of SMEs women and men funding participation rates & 0.07 & 3.44 & 0.95 \\
\hline Average financial contribution to SMEs for women & 0.05 & 1.24 & 0.97 \\
\hline Average value of financial contribution to SMEs for men & 0.10 & 3.88 & 0.95 \\
\hline Value of average deposits for women and men & 0.03 & 0.28 & 0.98 \\
\hline
\end{tabular}

Source: The data in the table are based on the results of the computational experiment. 
Analysis of the data given in column 2 of Table 1 showed that all calculated values are less than the critical value by the Kolmogorov-Smirnov test $(0.174)$ at a significance level of 0.05 . Similarly, data in column 3 are less than the table value of the Pearson test (9.49). The calculated values of the Shapiro-Wilk test exceed the table value 0.93 at a significance level of 0.01 . Thus, the computational experiment showed that all six developed functions are of high quality.

Density functions of normal distribution (1) to (6) provide an opportunity to identify a number of significant patterns that characterize the current financing of early-stage entrepreneurs in the countries under consideration. Average values of indicators are given in column 2 of Table 2. Column 3 of the same table shows the change intervals of indicator values for most countries.

Table 2. Values of indicators characterizing financing of early-stage entrepreneurs

\begin{tabular}{|l|c|c|}
\hline Indicators & $\begin{array}{c}\text { Average } \\
\text { values }\end{array}$ & $\begin{array}{c}\text { Values typical } \\
\text { for most } \\
\text { countries }\end{array}$ \\
\hline $\begin{array}{l}\text { Proportion of women participating in } \\
\text { the financing of new SMEs in the total } \\
\text { adult female population, \% }\end{array}$ & 3.23 & $1.26-5.20$ \\
\hline $\begin{array}{l}\text { Proportion of men participating in the } \\
\text { financing of new SMEs in the total } \\
\text { male adult population, \% }\end{array}$ & 4.86 & $2.31-7.41$ \\
\hline $\begin{array}{l}\text { Ratio of SMEs women and men } \\
\text { funding participation rates }\end{array}$ & 0.63 & $0.43-0.83$ \\
\hline $\begin{array}{l}\text { Average financial contribution to SMEs } \\
\text { for women, thousand dollars }\end{array}$ & 4.46 & $1.32-7.60$ \\
\hline $\begin{array}{l}\text { Average value of financial contribution } \\
\text { to SMEs for men, thousand dollars }\end{array}$ & 5.90 & $0.62-11.18$ \\
\hline $\begin{array}{l}\text { Value of average deposits for women } \\
\text { and men }\end{array}$ & 0.72 & $0.56-1.00$ \\
\hline
\end{tabular}

Source: Calculations were made by the author on the basis of functions (1) to (6).

Table 2 (column 2) shows that, in general, a small number of people participate in external financing of new SMEs. So, only one in thirty women and one in twenty men are involved in such investment activities. The average proportion of women participating in the financing of new SMEs in the total adult female population of the country, as shown in table 2, is 1.63 per cent lower than that of men. Men's greater activity in external financing of SMEs compared to women is also supported by an average ratio of 0.63. However, in countries such as Cyprus, the Republic of Korea and the Russian Federation, the participation of women and men in the external financing of SMEs is equal. And in four countries (Madagascar, the United Arab Emirates, Kazakhstan, Saudi Arabia), women are more active than men.
The average value of the financial contribution to SMEs for men is more than for women by $\$ 1440$. This follows from the data in column 2 of Table 2. Average values of financial contribution to SMEs are not very large, even for men they do not exceed $\$ 6000$. The ratio of average deposits for women to men is 0.72 . In countries such as Colombia, Italy, Poland, Slovenia, Thailand, Turkey, external contributions to SMEs women and men are almost equal. And in Australia, Madagascar, Greece, Cyprus, the Russian Federation, Indonesia, the average values of such deposits for women are higher than for men.

To test hypothesis 1 , the data presented in column 3 of Table 2 were analyzed. The analysis showed a significant differentiation of the values of each of the six indicators for the countries under review. Consequently, hypothesis 1 is confirmed.

The next phase identified countries with maximum and minimum values. The maximum values are the values exceeding the upper limits of the ranges specified in column 3 of Table 2 , and the minimum values are less than the lower limits of the specified ranges. The results of this analysis are shown in Table 3. In addition to the lists of countries, this table also shows the division of identified countries by their geographical situation and income level.

Table 3 shows the territorial location of countries with high (column 2) and low (column 3) values of each of the six indicators assessed in our study. Analysis of this information has shown that there are no links between these values and the territorial location of countries. That is, both high and low values are observed in various parts of the world. This made it possible to conclude that hypothesis 2 received confirmation.

An analysis of the data in column 2 of table 3 shows that the financial contribution to SMEs for women and men is significant only in high-income countries, which is logical. For countries with low financial contribution to SMEs for women and men (column 3), there is no link between these indicators and the income levels of the population in the countries concerned. The tables showed that there were no links between the income levels of the population in the countries and the values of the following four indicators, namely, the specific weights of women and men involved in financing new SMEs, the ratio of the values of the indicators of participation in financing SMEs, and the ratio of the average values of contributions. Thus, hypothesis 3 has been partially confirmed, as it is not implemented only for countries with financial contribution values for SMEs for women and men greater than the upper limits of the intervals in column 3 of table 2 . 
Table 3. Countries with high and low values of indicators

\begin{tabular}{|c|c|c|}
\hline Indicators & High values of indicators & Low values of indicators \\
\hline 1 & 2 & 3 \\
\hline $\begin{array}{l}\text { Proportion of women } \\
\text { participating in the } \\
\text { financing of new SMEs } \\
\text { in the total adult female } \\
\text { population, } \%\end{array}$ & $\begin{array}{l}\text { United Arab Emirates, Kazakhstan, Malaysia, } \\
\text { Taiwan, China, Angola, Guatemala, Saudi Arabia, } \\
\text { Chile, Sudan. Located in Europe ( } 2 \text { countries), in } \\
\text { Asia ( } 2 \text { countries), in Africa ( } 1 \text { country). Population } \\
\text { income: high income ( } 2 \text { countries), medium income } \\
\text { ( } 2 \text { countries), low income ( } 2 \text { countries). }\end{array}$ & $\begin{array}{l}\text { Puerto Rico, Bosnia and Herzegovina, India, Japan, } \\
\text { Qatar, Mexico, Brazil, Bulgaria, Egypt, the Russian } \\
\text { Federation. Located in Europe ( } 2 \text { countries), in Asia ( } 5 \\
\text { countries), in Latin America ( } 2 \text { countries). Population } \\
\text { income: high ( } 7 \text { countries), medium ( } 2 \text { countries). }\end{array}$ \\
\hline $\begin{array}{l}\text { Proportion of men } \\
\text { participating in the } \\
\text { financing of new SMEs } \\
\text { in the total male adult } \\
\text { population, } \%\end{array}$ & $\begin{array}{l}\text { Colombia, Saudi Arabia, Malaysia, } \\
\text { the USA, Austria, Iran, Estonia, Angola, Chile, } \\
\text { Guatemala, Sudan. Located in Europe ( } 2 \text { countries), } \\
\text { in Latin America ( } 3 \text { countries), in Asia ( } 3 \text { countries), } \\
\text { in Africa ( } 2 \text { countries), in North America ( } 1 \\
\text { country). Population income: high income ( } 5 \\
\text { countries), medium income ( } 3 \text { countries), low } \\
\text { income ( } 3 \text { countries). }\end{array}$ & $\begin{array}{l}\text { Bosnia and Herzegovina, the Russian Federation, } \\
\text { Madagascar, Puerto Rico, Indonesia, Qatar, Mexico, } \\
\text { South Africa, Cyprus, Brazil, India. } \\
\text { Located in Europe ( } 3 \text { countries), in Asia ( } 3 \text { countries), in } \\
\text { Africa ( } 2 \text { countries), in Latin America ( } 3 \text { countries). } \\
\text { Population income: high income ( } 4 \text { countries), medium } \\
\text { income ( } 4 \text { countries), low income ( } 3 \text { countries). }\end{array}$ \\
\hline $\begin{array}{l}\text { Ratio of SMEs women } \\
\text { and men funding } \\
\text { participation rates }\end{array}$ & $\begin{array}{l}\text { Greece, China, the Netherlands, Taiwan, Cyprus, } \\
\text { Madagascar, the United Arab Emirates, Kazakhstan, } \\
\text { the Russian Federation, Saudi Arabia. Located in } \\
\text { Europe ( } 4 \text { countries), } \\
\text { in Asia ( } 5 \text { countries), in Africa ( } 1 \text { country). } \\
\text { Population income: high ( } 5 \text { countries), medium ( } 4 \\
\text { countries), low ( } 1 \text { country). }\end{array}$ & $\begin{array}{l}\text { Puerto Rico, Egypt, India, Italy, Japan, Argentina, } \\
\text { Austria, Bulgaria, Ireland, Sweden. } \\
\text { Located in Europe ( } 5 \text { countries), in Asia ( } 2 \text { countries), in } \\
\text { Latin America ( } 2 \text { countries), in Africa ( } 1 \text { country). } \\
\text { Population income: high ( } 6 \text { countries), medium ( } \\
\text { countries), low ( } 2 \text { countries). }\end{array}$ \\
\hline $\begin{array}{l}\text { Average financial } \\
\text { contribution to SMEs } \\
\text { for women, thousand } \\
\text { dollars }\end{array}$ & $\begin{array}{l}\text { the Slovak Republic, Japan, Slovenia, Italy, Cyprus, } \\
\text { Switzerland, Greece, the Republic of Korea. Located } \\
\text { in Europe ( } 6 \text { countries), in Asia ( } 2 \text { countries). } \\
\text { Population income: high in all countries. }\end{array}$ & $\begin{array}{l}\text { Uruguay, Madagascar, Sudan, Angola, India, South } \\
\text { Africa, Panama, Guatemala, Ecuador, Mexico. Located } \\
\text { in Asia ( } 1 \text { country), in Africa ( } 4 \text { countries), in Latin } \\
\text { America ( } 5 \text { countries). } \\
\text { Population income: high ( } 2 \text { countries), medium ( } 4 \\
\text { countries), low ( } 4 \text { countries). }\end{array}$ \\
\hline $\begin{array}{l}\text { Average value of } \\
\text { financial contribution } \\
\text { to SMEs for men, } \\
\text { thousand dollars }\end{array}$ & $\begin{array}{l}\text { Cyprus, France, Greece, the Slovak Republic, Italy, } \\
\text { China, Luxembourg, Japan, Switzerland, Qatar, the } \\
\text { Republic of Korea. Located in Europe ( } 7 \text { countries), } \\
\text { in Asia ( } 4 \text { countries). } \\
\text { Population income: high in all countries. }\end{array}$ & $\begin{array}{l}\text { Madagascar, Uruguay, South Africa, Indonesia, Angola, } \\
\text { Panama, Guatemala, Sudan. } \\
\text { Located in Latin America ( } 3 \text { countries), in Asia ( } 1 \\
\text { country), in Africa ( } 4 \text { countries). Population income: } \\
\text { high ( } 2 \text { countries), medium ( } 2 \text { countries), low ( } 4 \\
\text { countries). }\end{array}$ \\
\hline $\begin{array}{l}\text { Value of average } \\
\text { deposits for women } \\
\text { and men }\end{array}$ & $\begin{array}{l}\text { Bulgaria, Madagascar, Australia, Cyprus, Greece, } \\
\text { the Russian Federation, Indonesia. } \\
\text { Located in Europe ( } 4 \text { countries), in Asia ( } 1 \text { country), } \\
\text { in Africa ( } 1 \text { country), in Australia ( } 1 \text { country). } \\
\text { Population income: high ( } 3 \text { countries), medium ( } 2 \\
\text { countries), low ( } 2 \text { countries). }\end{array}$ & $\begin{array}{l}\text { Bosnia and Herzegovina, Qatar, France, Luxembourg, } \\
\text { India, the Netherlands, Sudan, the USA, Angola, } \\
\text { Ecuador, Egypt. Located in Europe ( } 4 \text { countries), in Asia } \\
\text { ( } 2 \text { countries), in Africa ( } 3 \text { countries), in Latin America ( } 1 \\
\text { country), in North America ( } 1 \text { country). Population } \\
\text { income: high ( } 5 \text { countries), medium ( } 2 \text { countries), low ( } 4 \\
\text { countries). }\end{array}$ \\
\hline
\end{tabular}

\section{Conclusions}

Banks and other credit institutions are not the only source that are capable of meeting the financial needs of the emerging SMEs due to their increased requirements for small and medium enterprises. Alternative financing methods are frequently avoided by aspiring entrepreneurs, given their technology, structure and organization. On the other hand, entrepreneurs, with rare exceptions, do not wish to offer information transparency on how they intend to create and develop their businesses. Therefore, this article examines the pressing issue of external SMEs financing using funds acquired from individuals. At the same time, the major attention is paid to the gender characteristics of external financing, that is, the participation of women and men investors.

The study assesses the following indicators of external investments:

- the proportion of women and men participating in external financing of new SMEs within the total adult female and male population of the country;

- the ratio of participation rates in the external financing of the emerging SMEs for women and men; - the average financial contributions to the emerging SMEs by women and men residing in different countries;

- the proportion of the average contributions of women and men to the newly established SMEs.

This research has significant novelty and originality, which is described below. The assessment of the external investment indicators in SMEs by men and women in various countries is based on the development of economic and mathematical models, which are the functions of the 
normal distribution density. The validity of implementing such functions is confirmed by checking them using three different tests, which show the high level of quality for each of the functions and the decent level of the initial empirical data approximation. The obtained functions allow to determine the average values of each of the six indicators for the countries under consideration, as well as the ranges of their variation characteristic of most countries.

The research considers all the issues raised and questions posed. The average share of women living in the countries under consideration and participating in external financing of the emerging SMEs is $3.23 \%$. While the share of men residing in the analyzed countries who participate in the external financing of the recently established SMEs reaches $4.86 \%$. Consequently, the countries under review face a gender gap in the participation of women and men in informal financing of the start-up entrepreneurs. The average amount of the external financing for the emerging SMEs provided by women is $\$ 4460$. The average amount of the external financing for the start-up SMEs offered by men reaches $\$ 5900$. That is, the countries under consideration face a gender gap in the external financing of the emerging SMEs. It should be noted that there are significant variations across countries in the financing of the emerging SMEs, both in the number of men and women participating in it, and in the amount of funds provided. However, the countries' location does not significantly affect the values of each of the six indicators.

The results obtained are of theoretical and practical importance for government agencies and entrepreneurs. The significance of this study on external SMEs financing is explained by the potential application of its results by entrepreneurs, especially beginners, at the stage of raising funds in the process of establishing businesses. The findings obtained can be implemented by government bodies to develop policies for the facilitation of entrepreneurs' access to funds, as well as the formation of institutional norms that ensure the use of a wide range of the SMEs financing methods. In addition, the research results can be used to justify measures to improve the efficiency of financing the business sector, especially in the context of the crisis phenomena characteristic of recent years.

The proposed methodological approach used to assess the external financing of the emerging SMEs, taking into account the existing gender characteristics, can be applied in further research. The acquired innovative data is of interest and can be implemented in the educational process within the context of the higher institutions.

Further research is to be aimed at detailing the structure of the external financing recipients among entrepreneurs. The study has limitations on the empirical data due to the consideration of only 59 countries.

\section{REFERENCES}

[1] R. Decker, J. Haltiwanger, R. Jarmin, J. Miranda. The Role of Entrepreneurship in US Job Creation and Economic Dynamism. Journal of Economic Perspectives. Vol. 28. No 3. P. 3-24. 2014.

[2] V. Simon-Moya, L. Revuelto-Taboada, D. Ribeiro-Soriano. Influence of economic crisis on new SME survival: reality or fiction? Entrepreneurship and Regional Development. Vol. 28. No 1-2. P. 157-176. 2016.

[3] S. Kumar, P. Rao. A conceptual framework for identifying financing preferences of SMEs. Small Enterprise Research. Vol. 22. No 1. P. 99-112. 2015.

[4] New Approaches to SME and Entrepreneurship Financing: Broadening the Range of Instruments. analytical report. OECD Publishing. 152 p. 2015. DOI: 10.1787/9789264240 957-en.

[5] A. Karafo. Role of Equb in Financing Micro and Small Business Enterprises in Konso. Universal Journal of Accounting and Finance. Vol. 5. No 1. P. 1-8. 2017. DOI: 10.13189/ujaf.2017.050101.

[6] M. Godke Veiga, J.A. McCahery. The Financing of Small and Medium-Sized Enterprises: An Analysis of the Financing Gap in Brazil. European Business Organization Law Review. Vol. 20. P. 633-664. 2019. DOI: 10.1007/s40804-019-00167-7.

[7] A. Caggese. Financing constraints, radical versus incremental innovation, and aggregate productivity. American Economic Journal: Macroeconomics. Vol. 11. No 2. P. 275-309. 2019.

[8] M. Campello, M. Larrain. Enlarging the Contracting Space: Collateral Menus, Access to Credit, and Economic Activity. Review of Financial Studies. Vol. 29. No 2. P. 349-383. 2016.

[9] R. Cole, T. Sokolyk. Who needs credit and who gets credit? Evidence from surveys of small business finances. Journal of Financial Stability. Vol. 24. P. 40-60. 2016.

[10] OECD. High Growth Enterprises. What Governments can do to make a difference? OECD Publishing. 2010.

[11] OECD. Financing SMEs and Entrepreneurs 2012: An OECD Scoreboard, OECD Publishing. 2012.

[12] Z. J. Acs, S. Estrin, T. Mickiewicz, L. Szerb. Entrepreneurship, institutional economics, and economic growth: an ecosystem perspective. Small Business Economics. Vol. 51. No 2. P. 501-514. 2018.

[13] J. H. Block, M. G. Colombo, D. J. Cumming, S. Vismara. New players in entrepreneurial finance and why they are there. Small Business Economics. Vol. 50. P. 239-250. 2018 .

[14] A. Ferrando, A. Ruggieri. Financial constraints and productivity: evidence from Euro area companies. International Journal of Finance and Economics. Vol. 23. No 3. P. 257-282. 2018.

[15] S. Zubair, R. Kabir, X. Huang. Does the financial crisis change the effect of financing on investment? Evidence 
from private SMEs. Journal of business research. Vol. 110. P. 456-463. 2020

[16] Hui-Cheng Yu, Bor-Yuan Tsai, Beiling Ma. Information Transparency, Debt and the Cost of Equity Capital: Evidence from China. Universal Journal of Accounting and Finance. Vol. 7. No 3. P. 67-75. 2019. DOI: 10.13189/ujaf.2019.070301.

[17] P.M. Healy, K.G. Palepu. Information asymmetry, corporate disclosure, and the capital markets: A review of the empirical disclosure literature. Journal of Accounting and Economics. Vol. 31. No 1-3. P. 405-440. 2001.

[18] A. Lopes, C. Costa. Alternative sources of funding for SMEs in the Portuguese market. AESTIMATIO, the IEB International Journal of Finance. Vol. 15. P. 138-161. 2017.

[19] A. Moritz, J. H. Block, A. Heinz. Financing patterns of European SMEs- an empirical taxonomy. Venture Capital.
Vol. 18. No 2. P. 115-148. 2016.

[20] G. K. Ahlers, D. Cumming, C. Günther, D. Schweizer. Signaling in equity crowdfunding. Entrepreneurship: Theory and Practice. Vol. 39. No 4. P. 955-980. 2015.

[21] R. Kgoroeadira, A. Burke, A. Stel. Small business online loan crowdfunding: who gets funded and what determines the rate of interest. Small Business Economics. Vol. 52. No 1. P. 67-87. 2019.

[22] Global Entrepreneurship Monitor 2018/2019 Women's Entrepreneurship Report. Global Entrepreneurship Research Association (GERA). London Business School, London, United Kingdom. 2019.

[23] I. Pinkovetskaia, V. Slepova. Estimation of Fixed Capital Investment in SMEs: the Existing Differentiation in the Russian Federation. Business Systems Research. Vol. 9. No 1. P. 65-78. 2018. 